$\begin{array}{llr}\text { Jurnal Pendidikan Dasar Perkhasa } & \\ \text { http://jurnal.stkippersada.ac.id/jurnal/index.php/JPDP/ } & \text { P-ISSN 2461-078X } \\ \text { E-ISSN 2654-783X }\end{array}$

\title{
IMPLEMENTASI SUPERVISI KLINIS KEPALA SEKOLAH DALAM MENINGKATKAN PROFESIONAL GURU DI SD NEGERI 4 PENYAK LALANG
}

\author{
Marius* \\ SD Negeri 4 Penyak Lalang, Dinas Pendidikan Kabupaten Sintang \\ Diterima: 06 April 2020. Dipublikasi: 21 April 2020.
}

\begin{abstract}
This study aims to find out 1) Planning for the implementation of clinical supervision by principals in improving teacher professionalism in SD Negeri 4 Penyak Lalang clinical supervision solutions conducted by principals in improving teacher professionalism at SD Negeri 4 Penyak Lalang. This research approach uses descriptive qualitative research methods because this study explores the phenomena of the implementation process of the Principal's Clinical Supervision in Improving Teacher Professionals at SD Negeri 4 Penyak Lalang. The subjects of this research are those who will be examined include: Principal, and Teacher. This research was conducted at Penyak Lalang Public Elementary School 4, located in Penyak Lalang, Dedai District, Sintang Regency. In accordance with the qualitative research approach used, data collection techniques used by researchers are by observation analysis, interviews, and documentation studies. Data analysis begins by systematically searching and compiling data obtained from interviews, observations, and documentation, by organizing data into categories, arranging into patterns, choosing what is important and what will be studied, and making conclusions. Researchers used descriptive data analysis techniques. With this descriptive technique the researcher only intends to describe (describe) or explain the symptoms that are happening from the results of observations, interviews, and study documentation. The results of this study reveal the findings that the implementation of the clinical supervision of the school principal can increase the productivity and motivation of teachers and can improve teacher professionalism better.
\end{abstract}

Keywords: Reflective Learning Model, Discipline, Leaning Outcomes

Abstrak. Penelitian ini bertujuan untuk mengetahui 1) Perencanaan implementasi supervisi klinis yang dilakukan kepala sekolah dalam meningkatkan profesional guru di SD Negeri 4 Penyak Lalang 2) Hasil pelaksanaan implementasi supervisi klinis yang dilakukan kepala sekolah dalam meningkatkan profesional guru di SD Negeri 4 Penyak Lalang 3) Kendala dan solusi supervisi klinis yang dilakukan kepala sekolah dalam meningkatkan profesional guru di SD Negeri 4 Penyak Lalang. Pendekatan penelitian ini dengan menggunakan metode penelitian kualitatif deskriptif karena penelitian ini mengeskplor fenomena proses Implementasi Supervisi Klinis Kepala Sekolah dalam Meningkatkan Profesional Guru di SD Negeri 4 Penyak Lalang. Subjek penelitian ini orang yang akan diteliti diantaranya: Kepala sekolah, dan Guru. Penelitian ini dilakukan di SD Negeri 4 Penyak Lalang yang terletak di Penyak Lalang Kecamatan Dedai Kabupaten Sintang. Sesuai dengan pendekatan penelitian kualitatif yang digunakan, teknik pengumpulan data yang digunakan peneliti adalah dengan analisis observasi, wawancara, dan studi dokumentasi. Analisis data dimulai dengan mencari dan menyusun secara sistematis data yang telah diperoleh dari hasil wawancara, observasi, dan dokumentasi, dengan cara mengorganisasikan data kedalam kategori, menyusun kedalam pola, memilih mana yang penting dan yang akan dipelajari, dan membuat kesimpulan. Peneliti menggunakan teknik analisa data deskriptif. Dengan teknik deskriptif ini peneliti hanya bermaksud menggambarkan (mendeskripsikan) atau menerangkan gejala yang sedang terjadi dari hasil observasi, wawancara, dan study dokumentasi. Hasil penelitian ini mengungkapkan temuan bahwa dengan adanya implementasi supervisi klinis kepala sekolah ini dapat meningkatkan produktifitas dan motivasi kerjaguru serta dapat meningkatkan profesional guru yang lebih baik.

Kata kunci: Reflektive Learning, Kedisiplinan, Hasil Belajar 


\section{Pendahuluan}

Tuntutan untuk menjadi profesional mengharuskan guru memiliki komitmen yang jelas terhadap muridnya, sebab kehadiran dirinya di persekolahan secara langsung memang untuk mengembangkan potensi yang dimiliki siswa tersebut secara proporsional. Ketika ia menjalankan fungsi dengan komitmen yang tinggi, maka penguasaannya terhadap materi yang akan disampaikan benar- benar menyentuh kurikulum pembelajaran.

Guru profesional dalam konteks keilmuan adalah guru yang memahami filsafah mata pelajaran dari mata pelajaran yang diajarkan. Dengan demikian, guru telah memahami secara mendasar apa tujuan kurikulum dari setiap materi pelajaran sehingga materi bahan ajar tersebut terinternalisasikan dalam diri setiap siswa atau peseta didik ketika proses pembelajaran. Tuntutan ini adalah tuntutan yang selayaknya terealisir dalam diri guru, sehingga sifat keprofesionalan guru secara ontologi dan efistomologi dapat dipertanggung jawabkan secara akademik.

*surel korespondensi: mariusdedai@gmail.com
Guru berperan penting dalam keberhasilan sistem pendidikan. Hal ini dibuktikan melalui guru yang berkualitas dan berkompeten dalam bidang ilmunya ditiap jenjang pendidikan. Potensi guru harus terus dikembangkan agar melaksanakan fungsinya secara profesional, karena guru merupakan ujung tombak dalam peningkatan mutu pendidikan. Dalam pelaksanaan fungsi dan tugasnya, guru sebagai profesi yang menyandang persyaratan tertentu sesuai yangtertuang dalam Undang- undang Sistem Pendidikan Nasional Nomor 20 Tahun 2003 pasal 29 (1) dan (2) yang berbunyi, "Tenaga kependidikan bertugas melaksanakan administrasi, pengelolaan, pengembangan, pengawasan dan pelayanan teknis untuk menunjang proses pendidikan pada satuan pendidikan." Pendidik merupakan tenaga prefesional yang bertugas merencanakan dan melaksanakan proses pembelajaran, menilai hasil pembelajaran, melakukan bimbingan dan pelatihan, serta melakukan penelitian dan pengabdian kepada masyarakat, terutama bagi pendidik pada pergurua tinggi. Sesuai dengan tuntutan perubahan masyarakat, profesi guru 
Marius | JPDP 6 (1) April 2020, 95-106

senantiasa juga menuntut dari empat kompetensi, yaitu: (a)

profesionalismenya.

Guru profesional bukan hanya sekedar alat untuk tranmisi kebudayaan akan tetapi mentransfortasikan kebudayaan itu kearah budaya yang dinamis yang menuntut penguasaan ilmu pengetahuan, produktivitas yang tinggi dan kualitas kaya yang dapat bersaing. Guru profesional bukan lagi sosok yang berfungsi sebagai robot, tetapi merupakan dinamisator yang mengantar potensi- potensi pesera didik kearah pengembangan kreativitas. Tugas pokok seorang guru profesional meliputi tiga bidang utama, yaitu: (1) dalam bidang profesi, (2) dalam bidang kemanusiaan, (3) dalam bidang kemasyarakatan.

Secara

komprenshif, keprofesionalan guru saat ini dapat diukur dengan beberapa kompetensi dan indikator dan berbagai indikator yang melengkapinya, tanpa adanya kompetensi dan indikator itu maka sulit untuk menentukan keprofesionalan guru. Kompetensikompetensi yang meliputi keprofesionalan guru (berdasarkan Undang- undang No 14 Tahun 2005, tentang Guru dan Dosen) dapat dilihat
Kompetensi pedagogik,

Kompetensi kepribadian,

Kompetensi profesional dan

kompetensi sosial. Berdasarkan hasil penelitian Tanama dkk., (2016), kenyataannya masih banyak guru yang belum profesional. Selama ini dalam pelaksanaan pembelajaran banyak ditemui berbagai kendala. Proses pembelajaran yang tidak tepat menjadi salah satu penyebab kurang optimalnya prestasi belajar siswa, kurang tepatnya dalam menerapkan pembelajaran, kurangnya kesiapan guru dalam proses pembelajaran, kurangnya kreativitas guru dalam menyampaikan pelajaran menyebabkan siswa kesulitan dalam konsentrasi pembelajaran.

Semakin jelas bahwa mengajar memerlukan profesionalitas dan profesionalisme, sehingga mengajar adalah jabatan profesional yang saat ini dilindungi undang- undang tidak hanya menyediakan calon guru, rekrutmen guru, kesejahteraan guru, karir guru, tetapi juga pembinaan profesi guru secara berkelanjutan menjadi satu keniscayaan supaya pengetahuan, sikap dan keterampilan guru dalam melakukan pembelajaran 
terus terbina sejalan dengan tuntutan dan perubahan lingkungan eksteral dunia pendidikan.

$$
\text { Peningkatan mutu dan }
$$
profesionalisme guru dalam kinerjanya sangat berkaitan erat dengan efektivitas pelayanan supervisi. Kegiatan supervisi diharapkan mampu mendorong guru untuk meningkatkan kualitasnya dalam berbagai kompetensi baik kompetensi padagogik, kepribadian, profesional, maupun sosialnya sebagaimana disebutkan diatas. Hal ini sesuai dengan yang tertulis dalam Undang- undang Republik Indonesia No.14 Tahun 2005 tentang Guru dan Dosen. Guru adalah pendidik yang profesional dengan tugas utama mendidik, mengajar, membimbing, melatih, menilai dan mengevaluasi peserta didik pada pendidikan anak usia dini, jalur pendidikan formal, pendidikan dasar, dan pendidikan menengah.

Maka supervisi menjadi fokus utama dalam pendidikan karena Kegiatan supervisi dimaksudkan untuk memperbaiki situasi belajar mengajar di dalam kelas. Tujuan yang pokok adalah membantu para guru untuk tumbuh secara pribadi dan profesional, dan belajar untuk memecahkan sendiri masalahmasalah yang mereka hadapi dalam tugasnya.

Kepala sekolah dalam kedudukannya sebagai supervisor berkewajiban membina para guru agar menjadi pendidik dan pegajar yang baik. Bagi guru yang sudah baik agar dapat dipertahankan kualitasnya dan bagi guru yang belum baik dapat dikembangkan menjadi lebih baik. Sementara itu, semua guru yang baik dan berkompeten maupun yang masih lemah harus diupayakan agar tidak ketinggalan zaman dalam proses pembelajaran maupun materi yang menjadi bahan ajar.

Peran strategis guru dan staf dalam meningkatkan kualitas pendidikan hanya mungkin dapat dikembangkan dengan pembinaan dan pengembangan. Salah satu bentuk supervisi yang dapat dilakukan oleh kepala sekolah adalah dengan melakukan supervisi pendekatan supervisi klinis. Dimana pendekatan supervisi klinis ini dapat menggambarkan unsur- unsur dari sebuah pertemuansupervisor dengan guru yang bersepakat dan berencana 
untuk melakukan observasi pada saat pembelajaran langsung di kelas.

Berdasarkan hasil observasi di lapangan yang dilakukan oleh peneliti, terlihat bahwa dalam menyelenggarakan supervisi, kepala sekolah masih belum konsisten dalam penyelenggaraan supervisi klinis sehingga mendapatkan (1) kemoloran waktu (2) Masih kurangnya penguasaan kelas oleh guru (3) Guru kurang menguasai kompetensi yang diajarkan kepada siswa atau materi yang tidak sesuai dengan kompetensi yang seharusnya menjadi beban tugasnya (4) kurangnya kemampuan guru menciptakan pembelajaran yang variatif seperti pemanfaatan media pembelajaran internet, LCD dan media lainnya.

Berdasarkan hasil penelitian Agung dan Yufridawati seperti dikutip Awalyatun, dkk.

"Menyebutkan kenyataan di lapangan kerapkali menunjukan seorang guru yang menghadapi kesulitan dalam pelaksanaan pembelajaran, bersikap pasif dan kurang menunjukan upaya untuk mengatasinya. Salah satu cara yang mungkin di peroleh adalah dengan meminta bantuan dan bimbingan klinis dari kepala sekolah/ pengawas sekolah, tetapi hal ini tidak atau jarang terjadi."

Supervisi klinis merupakan jawaban untuk mengatasi permasalahan guru dalam pelajaran. Supervisi klinis sama halnya mendiaknosis orang sakit, maka guru juga mendapat diagnosis dalam proses belajar mengajar. Diagnosa dilakukan untuk menemukan aspek- aspek yang membuat tidak dapat mengajar dengan baik, kemudian aspek-aspek tersebut diperhatikan satu-persatu secara intensif. Dalam supervisi klinis cara pemberian obatnya dilakukan setelah supervisor mengadakan pengamatan secara langsung terhadap cara guru mengajar dengan menggunakan diskusi balikan antara supervisor dengan guru yang bersangkutan. Diskusi balikan adalah diskusi yang bertujuan untuk memperoleh balikan tentang kebaikan maupun kelemahan yang terdapat selama guru mengajar serta bagaimana usaha untuk memperbaikinya. Dan didukung dengan melanjutkan S1-S2, mengikuti sertifikasi, mengikuti pelatihan.

Menurut Glatthorn (1984) dalam Awalyatun, dkk. (2016: 58) menjelaskan bahwa supervisi klinis 
adalah "An intensive process designed to improve instruction by conferring with a teacher on lesson planning, observing the lesson, analyzing tthe observational data, and giving the teacher feedback about the observation." Pernyataan ini hendak menjelaskan bahwa supervisi klinis merupakan proses untuk meningkatkan proses pembelajaran melalui perbaikan rencana pembelajaran sampai memberikan umpan balik setelah pengamatan di kelas.

Berdasarkan pemaparan, dapat dikatakan bahwa supervisi klinis sangat perlu dilakukan untuk membantu guru dalam menjalani tugasnya. Atas dasar itu maka peneliti tertarik untuk melakukan penelitian dengan judul "Impelementasi Supervisi Klinis Kepala Sekolah dalam Meningkatkan Profesional Guru Di SD Negeri 4 Penyak Lalang".

\section{Metode}

Pendekatan penelitian ini dengan menggunakan metode penelitian kualitatif deskriptif karena penelitian ini mengeskplor fenomena proses Implementasi Supervisi Klinis Kepala Sekolah dalam Meningkatkan
Profesional Guru di SD Negeri 4 Penyak Lalang. Subjek penelitian ini orang yang akan diteliti diantaranya: Kepala sekolah, dan Guru. Penelitian ini dilakukan di SD Negeri 4 Penyak Lalang yang terletak di Penyak Lalang Kecamatan Dedai Kabupaten Sintang. Teknik pengumpulan data yang digunakan peneliti adalah dengan analisis observasi, wawancara, dan studi dokumentasi. Analisis data dimulai dengan mencari dan menyusun secara sistematis data yang telah diperoleh dari hasil wawancara, observasi, dan dokumentasi, dengan cara mengorganisasikan data kedalam kategori, menyusun kedalam pola, memilih mana yang penting dan yang akan dipelajari, dan membuat kesimpulan. Peneliti menggunakan teknik analias data deskriptif. Dengan teknik deskriptif ini peneliti hanya bermaksud menggambarkan (mendeskripsikan) atau menerangkan gejala yang sedang terjadi dari hasil observasi, wawancara, dan study dokumentasi.

\section{Hasil dan Pembahasan}

Hasil analisis penelitian ini diarahkan pada upaya menganalisis paparan penelitian untuk 
mengungkapkan hasil temuan observasi kelas yang akan dilakukan. penelitian yang berpedoman kepada fokus penelitian ini. berdasarkan pada paparan penelitian di atas, temuan yang dapat dikemukakan dalam kaitan implementasi supervisi klinis kepala sekolah dalam meningkatkan profesional guru di SD Negeri 4 Penyak Lalang.

1. Perencanaan implementasi supervisi klinis di sekolah SD Negeri 4 Penyak Lalang.

Menurut Mosher dan Purpel (Arif, 2008: 171) ada 3 aktivitas dalam proses supervisi klinik, yaitu: Tahap perencanaan, Tahap observasi, Tahap evaluasi dan analisis.

Tahap pertama dalam proses supervisi klinis adalah tahap pertemuan awal. Pertemuan awal ini dilakukan sebelum melakukan observasi kelas, sehingga banyak juga teoritis supervisi klinis menyebutkan dengan istilah tahap pertemuan sebelum observasi. Menurut Sergiovanni tidak ada tahap yang lebih penting daripada tahap pertemuan awal ini.

Tujuan utama pertemuan awal ini adalah untuk mengembangkan secara bersama-sama antara supervisor dan guru, kerangka kerja Hasil pertemuan awal ini adalah kesepakatan kerja antara supervisor dan guru. Tujuan ini bisa dicapai apabila dalam pertemuan awal ini tercipta kerja sama, hubungan kemanusiaan dan komunikasi yang baik antarasupervisor dan guru memilki pengaruh signifikan terhadap kesuksesan tahap berikutnya dalam proses supervisi klinik.

Dalam penelitian ini tentang perencanaan kegiatan supervisi klinis kepala sekolah dalam meningkatkan profesional guru di SD Negeri 4 Penyak Lalang bahwa kepala sekolah melakukan perencanaan dan itu sesuatu yang wajib bagi seorang kepala sekolah. Karena itu sudah menjadi program kepala sekolah dalam mengelolahnya. Kepala sekolah melakukannya dengan cara merancang perencanaan sendiri setelah itu didiskusikan bersama untuk memberikan tanggapan, masukan, dan sarannya. Apabila ada yang kurang ditambahkan dan apabila tidak cocok hilangkan atau hapuskan. Tetapi itu semua sesuai persetujuan kepala sekolah. Dalam perencanaan ini kepala sekolah melibatkan PKS 
kurikulum dan beberapa guru senior yang ada disekolah ini.

Program yang direncanakan kepala sekolah dalam melakukan supervisi klinis itu ada perminggu, perbulan dan persemester. Yang disupervisi kepala sekolah seperti datang keruangan-ruangan kelas untuk melihat kegiatan pembelajaran dikelas, apakah mereka melaksanakan kegiatan belajar mengajar, mempersiapkan perlengkapan pembelajaran seperti RPP atau silabus. Prota, prosem, penilaian, alat alat peraga, buku pengangan atau sebagainya. Tujuannya untuk mengetahui metode pembelajaran, standar kompetensi dan kompetensi dasar yang hendak dicapai guru dalam setiap pembelajaran yang dilaksanakan.

Pada kenyataannya, ketika dilakukan supervisi pembelajaran, ada didapati beberapa guru yang tidak sinkron antara RPP yang dibuat dengan yang diajarkan. Seharusnya apa yang tertulis dalam RPP itulah yang tertuang dalam kegiatan pembelajaran. Hanya sedikit penambahan itu tidak menjadi masalah, namun yang terjadi penambahan itu mencapai keseluruhan isi RPP. Hal ini sangat bertentangan dengan acuan yang telah ditetapkan. Pada dasarnya RPP adalah pegangan guru ketika ia mengajar dan seharusnya RPP itu bukanlah formalitas, namun memang benarbenar pedoman persiapan ketika mengajar.

Selain RPP, media pembelajaran dan penguasaan kelas juga menjadi masalah bagi guru. Sebagian guru tidak mampu menguasai kelas namun sebagian guru sudah dapat menguasai kelas, upaya yang dilakukan kepala sekolah untuk mengatasi penguasaan kelas adalah dengan melakukan teknik supervisi yang bersifat individual. Sedangkan untuk mengatasi masalah yang dihadapi guru berkaitan dengan RPP, maka upaya yang dilakukan kepala sekolah adalah dengan mengikuti pelatihan diluar atau didalam sekolah.

Temuan kedua Berkaitan dengan profesional guru berdasarkan Undang- undang No 14 Tahun 2005, tentang Guru dan Dosen dapat dilihat dari empat kompetensi, yaitu:

(a) Kompetensi pedagogik, (b) Kompetensi kepribadian, Kompetensi profesional dan kompetensi sosial dan sertifikasi 
sebagai syarat menjadi guru yang profesional. Terdapat 17 guru yang telah sertifikasi dan mampu bersikap profesional, namun ada pula yang masih belum bisa bersikap profesional.

Letak ketidak profesionalan guru terletak pada kompetensi profesionalnya. Sebab masih ada guru yang tidak sesuai dengan latar belakangnya. Sehingga guru tersebut kurang dapat menguasai kelas dan guru kurang menguasai kompetensi yang diajarkan kepada siswa atau materi yang tidak sesuai dengan kompetensi yang seharusnya menjadi beban tugasnya. Kemudian dalam segi kompetensikepribadiannya. Sebab seorang guru tidak mampu menempatkan diri kapan dia menjadi guru, kapan menjadi seorang sahabat, kapan menjadi orang tua. Tidak mengindahkan larangan atau aturanaturan yang telah dibuat. Kapan larangan itu untuk dirinya dan kapan larangan itu untuk sekolah.

Lemahnya komunikasi dan tidak adanya seni dalam hubungan sosial dengan sesama guru maupun siswa. Sehingga memicu konflik antara guru dan siswa yang disebabkan oleh tingkah laku yang belum profesional tersebut. sifat sifat ini harus dihindari oleh seorang guru seharusnya memiliki sikap yang lembut, ramah, dan dapat memposisikan dirinya sebagai seorang guru dimanapun dia berada sekalipun didalam lingkungan masyarakat.

Dari penjelasan diatas dapat peneliti simpulkan bahwa kepala sekolah dalam menjalankan supervisi klinis dalam meningkatkan profesional guru. Pertama, kepala sekolah melakukan perencanaan terlebih dahulu, yang mana perencanaan tersebut disesuaikan dengan kebutuhan guru dalam peningkatan profesionalisme guru. Kedua, pelaksanaan yang mana kepala sekolah mengikut sertakan guru-guru dalam pelatihan, workshop, serta studi lain guna meningkatkan profesional guru baik pelatihan yang diadakan kepala sekolah maupun dari sekolah luar. Ketiga, program yang direncanakan kepala sekolah ada perminggu, perbulan dan persemester. Kemudian guru- guru yang ada disekolah SD Negeri 4 Penyak Lalang sudah dapat dikatakan guru yang profesional akan tetapi ada sebagian guru yang belum. Dan kepala 
sekolah harus peka dalam hal ini dan bisa dapat mengatasi masalah ini.

2. Hasil pelaksanaan supervisi klinis yang dilakukan kepala sekolah

Setelah melakukan kunjungan dan observasi kelas, maka supervisor seharusnya dapat menganalisis datadata yang diperoleh tersebut untuk diolah dan dikaji dan dapat dijadikan pedoman dan rujukan pembinaan dan peningkatan mutu guru-guru selanjutnya. Masalah-masalah profesional yang berhasil diidentifikasi selanjutnya perlu dikaji lebih lanjut dengan maksud memahami esensi masalah yang sungguhnya dan faktor-faktor penyebabnya, selanjutnya masalahmasalah tersebut diklasifikasi dengan maksud untuk menemukan masalah yang mana yang dihadapi oleh kebanyakan guru di sekolah atau di wilayah itu.

Ketepatan dan kehati-hatian supervisor dalam menimbang suatu masalah akan berpengaruh terhadap keberhasilan proses pembinaan profesional guru yang bersangkutan selanjutnya.

Dari hasil wawancara dengan kepala sekolah dan beberapa guru yang mana memberikan dampak positif dan guru- guru disekolah ini kebanyakan dapat dibina, walaupun sebagian ada juga yang sedikit sulit untuk dibina dengan demikian perubahan tentunya juga pasti ada dalam menjalankan kegiatan pembelajaran dengan baik seperti menggunakan RPP dan guru- guru tersebut juga semakin mengerti tugas sebagai pendidik yang profesional. Dari pemaparan diatas dapat ditarik kesimpulan bahwasanya kepala sekolah melakukan evaluasi. Tetapi tidak sesuai dengan prosedur atau siklus yang telah dipapar dipembahasan.

3. Kendala dan solusi terhadap kegiatan supervisi yang dilakukan kepala sekolah

Kendala yang didapati di sekolah SD Negeri 4 Penyak Lalang dalam melaksanakan kegiatan supervisi yaitu waktu, sarana prasarana, kurangnya guru dalam mata pelajaran umum dan faktor ekonomi. Jadi bagi kepala sekolah solusi yang diberikan dengan diadakan rapat dewan guru. Penerapan peraturan sekolah dan bagi guru kurang dalam segi ekonomi maka kepala sekolah memberikan jam tambahan dengan hal itu diharapkan 
guru tersebut dapat tertolong melaksanakan tugasnya sebagai sehingga pada waktu mengajar dapat pendidik yang profesional. (2) Hasil berkonsentrasi secara penuh.

\section{Simpulan}

Berdasarkan temuan penelitian dan pembahasan hasil penelitian mengenai implementasi supervisi klinis kepala sekolah dalam meningkatkan profesional guru di SD Negeri 4 Penyak Lalang, dapat ditarik kesimpulan sebagai berikut: (1)Perencanaan Program supervisi klinis yang dilaksanakan oleh kepala di SD Negeri 4 Penyak Lalang, pertama kepala sekolah membuat program, kedua Penyusunan program, ketiga menjalankan program supervisi klinis.

Dalam perencanaan ini kepala sekolah melibatkan PKS kurikulum dan beberapa guru senior yang ada disekolah ini. Program yang direncanakan kepala sekolah dalam melakukan supervisi klinis itu ada perminggu, perbulan dan persemester. Supervisi klinis yang ditelah dilaksanakan oleh kepala sekolah di SD Negeri 4 Penyak Lalang Perbaungan sangat memberikan keuntungan kepada guru-guru, sehingga guru mengetahui akan kelemahan dan kekurangannya dalam 
ketidaksingkronan antara RPP yang dibuat dengan ditampilkan. Dan adanya tidak lanjut untuk kepala sekolah dalam memberikan pelatihanpelatihan kepada guru- guru baik pelatihan yang diadakan kepala sekolah sendiri maupun pelatihan yang diadakan oleh pemerintah. Sehingga guru bisa lebih baik lagi dalam membuat dan menjalankan ketika dalam proses pembelajaran. (3)Guru- guru harus memiliki sifat ikhlas beramal dalam bekerja yaitu sesuai dengan tugasnya sebagai guru: mendidik, mengajar, mengarahkan, membimbing melatih, menilai dan mengevaluasi peserta didik.

\section{DAFTAR PUSTAKA}

Arif, S. (2008). Implementasi Supervisi klinis Dalam Pendidikan Agama Islam. Tadris. $3(2)$.

Awalyatun, R. Wau, Y., Rangkuti, I. (2016). Implementasi Supervisi
Klinis Oleh Pengawas Sekolah di Kota Takengon. Jurnal Manajemen Pendidikan Indonesia. 8(1) p. 54-66.

Pemerintah Republik Indonesia. (2003). Undang-Undang nomor 20 tahun 2003 tentang Sistem Pendidikan Nasional.

Pemerintah Republik Indonesia. (2005). Undang-Undang nomor 14 tahun 200 tentang Guru dan Dosen.

Pusat Pengembangan dan Pemberdayaan Pendidik dan Tenaga Kependidikan.

Tanama. Y.J., dkk. (2016), "Impementasi Supervisi Klinis Dalam Meningkatkan Profesionalisme Guru”, Jurnal Pendidikan: Teori, Penelitian, Pengembangan, http :// jurnal. Unmal.ac.id/, (Diakses tanggal 19 Januari 2018). 